\title{
Beyond Quietism: Transformative Experience in Pyrrhonism and Wittgenstein
}

\author{
Rico Gutschmidt \\ Assistant Professor, Department of Philosophy, University of Konstanz, \\ Konstanz, Germany \\ rico.gutschmidt@uni-konstanz.de
}

\begin{abstract}
Pyrrhonian skepticism is usually understood as a form of quietism, since it is supposed to bring us back to where we were in our everyday lives before we got disturbed by philosophical questions. Similarly, the 'therapeutic' and 'resolute' readings of Wittgenstein claim that Wittgenstein's 'philosophical practice' results in the dissolution of the corresponding philosophical problems and brings us back to our everyday life. Accordingly, Wittgenstein is often linked to Pyrrhonism and classified as a quietist. Against this reading, I will employ Laurie Paul's notion of epistemically transformative experience and argue that Pyrrhonian skepticism and Wittgenstein's philosophy can be interpreted as a philosophical practice that changes our self-understanding in significant ways. I will argue that this practice can evoke transformative experiences and is thereby able to yield a non-propositional insight into the finitude of the human condition. This shows that Pyrrhonian skepticism and Wittgenstein's philosophy go beyond quietism.
\end{abstract}

\section{Keywords}

skepticism - Pyrrhonism - Wittgenstein - quietism - transformative experience

\section{Introduction}

Pyrrhonian skepticism is usually understood as a form of quietism, since it is supposed to bring us back to where we were in our everyday lives before we got disturbed by philosophical questions. Similarly, the 'therapeutic' and 'resolute' readings of Wittgenstein claim that Wittgenstein's 'philosophical practice' 
results in the dissolution of the corresponding philosophical problems and brings us back to our everyday life. Accordingly, Wittgenstein is often linked to Pyrrhonism and classified as a quietist.

Against that, I will argue that although Pyrrhonian skepticism and Wittgenstein's philosophy indeed share the strategy of dissolving philosophical problems, they do not necessarily just bring us back to where we were before. In particular, I build upon interpretations of Pyrrhonism and Wittgenstein according to which both performatively undermine our quest for absolute objectivity and show us that the very notion of absolute objectivity is confused. The dissolution of this confusion leads us to acquiesce in our finite and plain everyday world without being bothered anymore about the supposed need for objective knowledge. Against this quietist reading, I will argue that the philosophical practices of both Pyrrhonism and Wittgenstein not only show that we are confused about the quest for absolute objectivity, but reveal at the same time an important insight about our finitude. If we accept as a result of the skeptical practice that the notion of 'absolute objectivity' is confused, we have to accept that the notion of 'finitude' is confused as well, since it can be understood only against the background of the quest for absolute objectivity. Thus, we do not fully understand what 'finite' is supposed to mean in this context. Without a concept of absolutely objective knowledge in hand, we are in no position to state that our knowledge is non-objective or 'finite.' We still understand these contrasting notions to some extent, but only metaphorically or, as Cavell puts it, as conceptual projections (1979: 180-190). In the context of skepticism, Cavell claims that such notions are still intelligible: "If not fully, still not fully not" (1969: 250). In the end, however, the notion of 'finitude' cannot be used to express or illuminate something determinant about the nature of the human condition, since it is not fully understandable.

My claim is that, in its appeal to human 'finitude', the quietist reading misses this point. In addition, I think that there is a certain non-propositional insight into our finitude that is linked to the experience of the failure of the quest for absolute objectivity; this insight into our finitude, one might put it, is not so much abstractly understood as it is concretely experienced. We metaphorically understand the notion of 'finitude' to a certain extent, but I will argue that there is an additional, very particular, and experiential understanding of 'finitude' that is missing in the quietist acquiescence in the finite everyday world. In particular, I will argue that the performative undermining of the quest for absolute objectivity by Pyrrhonian skepticism and Wittgenstein's philosophy can be interpreted as a practice that yields such non-propositional, experiential insight into the finitude of the human condition and, thus, goes beyond quietism. 
To this end, I will refer to Pierre Hadot's thesis that ancient philosophy as well as Wittgenstein's philosophy are directed more toward a way of life than toward theoretical knowledge. Moreover, I will transpose Laurie Paul's notion of epistemically transformative experience from decision theory to the realm of philosophical practice and argue that the performative undermining of the quest for absolute objectivity by Pyrrhonian skepticism and Wittgenstein's philosophy yields an epistemically transformative experience in Paul's sense. I am not, however, concerned to establish that Wittgenstein or Pyrrhonians were self-consciously aiming at such philosophical transformations. Without addressing the question of whether they set out to evoke the sort of transformative philosophical experience I attempt to describe, I will show that their respective philosophical practices can evoke such experiences.

\section{Pyrrhonism, Wittgenstein, and Philosophy as a Transformative} Practice

Philosophy, from its ancient beginnings to the present day, is not best conceived of as a purely theoretical endeavor. Rather, it has strong practical aspects. In contrast to most of his Presocratic predecessors, Plato, for example, argues that 'true' (alêthê) philosophy aims not at theoretical solutions, but at 'the turning of the soul': it is a practice of psychês periagôgê (Republic, Book 7 , 521c). This turning is said to be achieved by education or paideia, which makes use of theoretical statements, but in the end this education is best understood not as the conclusion of pure theorizing, but rather as a product of craft, skill, or expertise (technê) that, as such, aim at a practical end (Republic, Book 7, 518d). According to Pierre Hadot (1995), Martha Nussbaum (1994), Myles Burnyeat (1983), and others, this concept of a 'turn' (periagôgê) or similar accounts of transformation can be found in many schools of ancient philosophy, so that ancient philosophy can be conceived of as fundamentally a practice of personal transformation. As Hadot puts it: "Philosophy then appears in its original aspect: not as a theoretical construct, but as a method for training people to live and to look at the world in a new way. It is an attempt to transform mankind" (1995: 107).

Though in a way importantly different from all or most other ancient philosophical schools, the same is true of the Pyrrhonian school of ancient skepticism. While most of the schools of ancient philosophy were seeking a transformation towards the happiness of wisdom with the help of knowledge, for Pyrrhonists an equivalent transformation is achieved in the very moment of the failure of the attempt to gain philosophical knowledge. Pyrrhonian 
skepticism is a method or an ability to challenge philosophical claims or arguments with equally credible (pistin) counterclaims or counterarguments with the aim of inducing the equipollence (isostheneia) of the opposing positions. This leads to suspension of judgment (epochê), which is then followed by a state of tranquility (ataraxia) ( $P H$ I $8-10) .{ }^{1}$ This is, of course, a very coarsegrained representation of Pyrrhonism, and I will neither discuss all the details nor refer to the enormous debate surrounding them. ${ }^{2}$ However, Pyrrhonian skepticism surely is a practice of transformation in Hadot's sense, and I shortly want to explore the scope and the status of the skeptical method. This exploration is neither meant to be an explication of Pyrrhonian Skepticism in general nor of Sextus Empiricus in particular. Instead, I want to propose a plausible reading of Pyrrhonism and argue that it can be interpreted in such a way that it evokes transformative experiences. I am not concerned with the question whether Pyrrhonians actually intended to do so.

As for the scope, Sextus Empiricus distinguishes sceptics from dogmatists by claiming that Pyrrhonians "live in accordance with everyday observances" ( $P H$ I 23) and that they do not make any statements that are supposed to describe things as they really are or as they are by nature as opposed to how they appear to us to be ( $\mathrm{PH}$ I 4). ${ }^{3}$ There are important similarities between Sextus's appearance-reality distinction and the distinction made by Thompson Clarke between the 'plain' and the 'philosophical', and it is indeed helpful to apply Clarke's distinction to Pyrrhonism. ${ }^{4}$ In his influential paper "The Legacy of Skepticism", Clarke refers to the quest for absolute objectivity and distinguishes 'philosophical' questions from 'plain' questions against this background: "The truth is, I think, that this simple quest for absolute objectivity drives us beyond the plain, moving us to philosophize" (1972: 762). Of course, the concept of 'absolute objectivity' cannot be found explicitly in ancient skepticism, even though something like a notion of 'absolute objectivity' is implied in the philosopher's notion of the truth that corresponds with reality. However, I am following Roger Eichorn's reading according to which Sextus' notion of dogmatism is best understood as a metadoxastic attitude, namely as "the belief that one's beliefs enjoy objective justification, that they represent how things are 'by nature"' (2014: 130; cf. also Barnes 1982). In Clarke's terms, the dogmatist thinks

1 In what follows, $P H$ is used as shorthand for Sextus Empiricus's Outlines of Pyrrhonism (Pyrrhōneioi Hupotupōseis), and $M$ is used as shorthand for Sextus Empiricus, Against the Logicians and Against the Ethicists (Adversus Mathematicos VIII and XI).

2 Cf., e.g., Bailey (2002), Machuca (2011), and Vogt (2015).

3 Cf. also $P H$ I 135, 223 and $M$ XI 18-19.

4 This is discussed in Bett (1993), Burnyeat (1998), and Eichorn (2014). 
that he transcends the circle of the plain and knows how things really are while the skeptic sticks to the appearances of the plain and suspends judgement on the 'true reality' of things. This is, of course, a very complex interpretative issue and there are many other interpretative options available. For the purpose of this paper, though, it suffices to present a single plausible interpretation that allows me to argue that Pyrrhonism can be understood as a practice that yields a non-propositional insight into the finitude of the human condition. In this context, Eichorn also reinterprets the famous 'insulation' reading according to which philosophy and everyday life are insulated from each other in the sense that neither has a direct bearing on the other. Since philosophy is 'insulated' from everyday claims in this way, skepticism can target philosophy without impugning everyday claims (cf., e.g., Burnyeat 1998). On Eichorn's reading, the skeptical method can be understood as applying to every belief, but only insofar as the dogmatist claims to have a philosophical justification of it: "If a claim is advanced as part of or on the basis of a dogmatic philosophical theory, Pyrrhonians will suspend judgment on it qua dogmatic claim; but if the very same claim is made in the context of the observances of everyday life, Pyrrhonians are free to assent to it qua everyday claim" (2014: 127). Accordingly, the Pyrrhonian skeptic assents to everyday life 'without doxa' (adoxastos) (PH I 15), which, though it literally means 'without belief' or 'opinion', is better understood as meaning 'without dogma', i.e., without knowledge that is 'philosophical' in Clarke's sense.

It is important to recognize, though, that according to Sextus Empiricus, Pyrrhonian skepticism does not entail holding the claim or position that philosophical knowledge is impossible to attain. Sextus attributes this claim to Academic skepticism and states that, in contrast, the Pyrrhonian skeptics "are still investigating" ( $P H$ I 3 ). Thus, the skeptical method is applied not only to single instances of seeming philosophical knowledge, but also to the very question of whether philosophical knowledge is possible. This seems to be at odds with the skeptical method that is supposed to find for every position or argument an equally credible counterargument, which somehow implies that philosophical knowledge is ultimately impossible to attain. However, Sextus Empiricus is well aware of the self-defeating character of such 'theoretical' skepticism. He uses two strategies to deal with the contradictive appeal of the Pyrrhonian skeptical method. The first strategy is to proclaim that the skeptic does not make any statements that are supposed to be true in the philosopher's sense. Instead, according to Sextus, skeptics "report descriptively on each item

5 Cf. also $P H$ I 23, 226, 240, II 102, 246, 254, 258, III 2, 151 .

6 Eichorn (2014: 133); similarly Vogt (2015: 27-28). 
according to how it appears to us at the time" ( $P H$ I 4). This also applies to the skeptical method itself, which is described in such a way that it only appears to be effective. The second strategy is more sophisticated, since it directly faces the problem that the skeptical method seems to undermine itself. Sextus addresses this self-defeating character of his skeptical account quite directly when he maintains that the skeptics "suppose that [...] the phrase "Everything is false' says that it too, along with everything else, is false" ( $P H$ I 14). Obviously, Sextus embraces the apparent incoherence of his approach by admitting that the skeptical method just is self-defeating. It is part of the skeptical method that the skeptics "utter their own phrases in such a way that they are implicitly cancelled by themselves" ( $P H$ I 15; cf. also $P H$ II 188). Sextus does not even think that this is incoherent. In contrast, he claims that " $[t]$ his is not incongruous, since the phrase 'Nothing is true' not only denies everything else but also turns itself about at the same time" ( $P H$ II 188). Since the skeptic does not end with theoretical knowledge-claims, there cannot be an incoherence. However, the skeptical method still employs theoretical statements, and it is part of the method that these statements can indeed, as theoretical, be incoherent or contradict each other. Accordingly, the Pyrrhonian skeptical method is explicitly self-defeating, which is underlined by Sextus in three famous metaphors that compare the method with fire that consumes the wood and thus destroys itself as well ( $M$ VIII 480), with purgative drugs that are driven out of the body after they have achieved their effect ( $M$ VII 480 ; cf. also PH I 206, II 188), and with a ladder that can be thrown away after its use ( $M$ VIII 481$){ }^{7}$

Thus, Pyrrhonian skepticism does not assert a theoretical position concerning the possibility of philosophical knowledge. Instead, the skeptical method can be understood as a practice that performatively undermines the seeming philosophical knowledge that Sextus attributes to dogmatists. More precisely, the Pyrrhonian's performative undermining of seeming philosophical knowledge can be understood as the subversion of the belief of knowing how things really are as opposed to how they appear to us to be, which in turn can be rephrased in modern terms and with reference to Clarke as the performative undermining of the quest for absolute objectivity. In addition, Sextus' remarks on the skeptical method are not to be understood as a theoretical statement about this practice, but rather as its description. Aside from the above-quoted opening remarks, his Outlines of Pyrrhonism can be conceived of as a handbook that first describes different skeptical methods (Book I) and then applies them as a philosophical practice (Books II and III). Also, he is not claiming to know

7 These metaphors resemble the famous Buddhist parable of the raft that can be used for crossing the water and is not needed anymore afterwards. 
that these skeptical methods will work as they are supposed to work or as they seemed to work for Sextus himself. In contrast, he proposes only methodological recipes that might work in a performative way. Sextus was also a physician, and at the very end of his Outlines he relates his account of skepticism to a medical cure or therapy ( $P H$ III 280-281). In particular, he claims that the skeptics wish to cure "the conceit and the rashness of the Dogmatists" ( $P H$ III 280) ${ }^{8}$ and that there are different therapies or treatments for different strengths of the dogmatist's illness, which also indicates that, for Sextus, no single therapy or treatment is guaranteed to work in any particular case.

To sum up, the philosophical practice of Pyrrhonism can be interpreted as a performative therapy that is supposed to cure us of the erroneous dogmatic assumption that our beliefs are objectively justified. The performative skeptical practice explicitly makes use of incoherent or paradoxical arguments that are cancelled out by themselves. It does not result in a theoretical claim about philosophical knowledge, but rather gives rise to a transformation of the self towards the ataraxia of the life adoxastos. This self-understanding of Pyrrhonian skepticism - the idea of philosophy not as aiming at theoretical statements, but as a therapeutic, transformative practice-is a commonplace throughout the history of philosophy. As quoted above, according to Plato, philosophical reasoning does not aim to establish theories, but has to be understood as a practice that changes the human who is dealing with philosophical questions. Socrates' way of doing philosophy is a paradigm example of this. Of course, the philosophical practice includes making and evaluating theoretical statements, since otherwise it would not be a philosophical practice. But although it makes use of theoretical statements, philosophy does not have to give rise in the end to a theoretical position. Instead, it can be conceived of as a practice that leads to a transformation of the self. This approach to philosophy can be attributed not only to Plato, Socrates, and ancient philosophy in general, but also to the works of, for example, Montaigne, Rousseau, Schopenhauer, Nietzsche, and - albeit implicitly — even those of Descartes, Spinoza, and Kant. In more recent times, versions of the demand of 'turning the soul' and of philosophy as a transformative practice can be found in the works of such diverse thinkers as Dewey, Wittgenstein, Heidegger, Derrida, and Rorty, and the corresponding performative aspects of philosophy are highlighted in the accounts of, among others, Deleuze, Guattari, Foucault, and Kristeva. Not least, Stanley Cavell explicitly states that his philosophy is aiming at the "education of grown-ups," which is associated with a transformation or even conversion. This strongly resembles the abovementioned concepts of periagôgê and paideia in Plato: "And

8 Cf. also $P H$ I 20, 177, 205, 212, 237, II, 21, III, 2. 
for grown-ups this is not natural growth, but change. Conversion is a turning of our natural reactions" (1979: 125).

In the context of skepticism, the most important twentieth-century account of philosophy as a transformative practice can be found in the works of Wittgenstein. Already in 1959, Pierre Hadot elucidated the practical and transformative aspects of Wittgenstein's philosophy that fit well into Hadot's overall understanding of ancient philosophy. ${ }^{9}$ Recently, a transformative understanding of Wittgenstein's philosophy has been established in its various therapeutic readings (cf. Crary 200o). Moreover, Wittgenstein's philosophy has also been explicitly related to Pyrrhonism. ${ }^{10}$ As I have argued above, Sextus is not aiming ultimately at philosophical theories, not even at a theoretical position. Similarly, the therapeutic readings of Wittgenstein propose, as Alice Crary puts it, an "understanding of Wittgenstein as aspiring, not to advance metaphysical theories, but rather to help us work ourselves out of confusions we become entangled in when philosophizing" (2000:1). This aspect of Wittgenstein's philosophy is highlighted not only in its therapeutic readings, but more thoroughly in the 'resolute reading' that is most prominently advocated by Cora Diamond and James Conant. According to them, the Tractatus does not establish any theory or position, but seeks to free the reader from philosophical illusions by way of first entering them and then letting them explode from within (cf., e.g., Conant 2000: 197-198). The starting point of the 'resolute reading' is sentence 6.54 of the Tractatus, where Wittgenstein claims that the sentences of the Tractatus are nonsensical and where he reuses the famous metaphor of the ladder that he most probably got, though indirectly, from Sextus. ${ }^{11}$ The strategy that the 'resolute reading' ascribes to Wittgenstein resembles very much the Pyrrhonian strategy of performatively undermining seeming philosophical knowledge. While Sextus proposes different cures to this end, depending on the degree of the philosophical malady in question ( $P H$ III $280-281$ ), Wittgenstein also proposes to use different therapies: "There is not a single philosophical method, though there are indeed methods, different therapies, as it were" (2009: §133d). Not least, as the arguments of the Pyrrhonian skeptics are implicitly cancelled by themselves, Wittgenstein insists that his way of doing philosophy is just a way and not a position, not even a position about this way:

9 Hadot (1959); cf. also Hadot (2004). Similarly, Wallgren (2006) establishes a transformative understanding of ancient philosophy and relates it to Wittgenstein.

10 Cf., e.g., Watson (1969), Fogelin (1987), Plant (2004), Sluga (2004), and Pritchard (2011b).

11 Hans Sluga points out that Ernst Mach borrowed the metaphor from Sextus and that Fritz Mauthner in turn borrowed it from Mach. Mauthner, finally, was an important influence on Wittgenstein's philosophy, so that Wittgenstein may have borrowed the metaphor from him. Cf. Sluga (2004: 103). 
"All that philosophy can do is to destroy idols. And that means not creating a new one-say in the 'absence of an idol'" (2005: 305e).

In addition to these analogies concerning the status of the transformative therapies of Sextus and Wittgenstein, there is also a strong analogy with respect to their aim. In particular, I think that Clarke's notion of philosophy as the quest for absolute objectivity is helpful to understand Wittgenstein's practice too. According to the therapeutic readings, Wittgenstein wants to free us from philosophical confusions, one of which is the quest for absolute objectivity, which can also be understood as the quest for an external standpoint. With respect to the concept of an external viewpoint on language, Crary summarizes the therapeutic readings of Wittgenstein by claiming that according to these readings, Wittgenstein's "fundamental aim is to get us to see that the point of view on language we aspire to or think we need to assume when philosophizing - a point of view on language as if outside from which we imagine we can get a clear view of the relation between language and the world-is no more than the illusion of a point of view" (2000: 6). Of course, Wittgenstein strives against all kinds of philosophical confusions. It is safe to say, though, that he is particularly concerned to undermine the quest for an absolute foundation of our knowledge, most notably in On Certainty (cf., e.g., Gutschmidt 2016). Wittgenstein's philosophical practice can thus be interpreted in a way that is very close to the interpretation of Pyrrhonism that I outlined above. According to this reading, both cases represent a philosophical practice that performatively undermines our quest for absolute objectivity and shows us that this quest is confused.

\section{The Quietist Objection}

Now, it can seem that, after the dissolution of our confusion, we understand ourselves just the same as we did before, only now we no longer concern ourselves with philosophical puzzles that we recognize as illusory. This is the main claim of the quietist reading of Sextus and Wittgenstein. In this context, quietism refers to the idea that we first live in our everyday practices and then get puzzled by philosophy. We can be cured of these puzzlements only by another philosophical practice that dissolves the initial philosophical problems in such a way that we finally understand that we have been simply confused. Then everything returns to the way it was before: we are back in our everyday practices without philosophical confusions. ${ }^{12}$ This kind of quietism is often ascribed to Pyrrhonism (cf., e.g., Gabriel 2008: 86-92). In twentieth-century philosophy,

12 Cf., e.g., Virvidakis (2008) for a more detailed discussion of quietist positions. 
quietist positions can be found in the ordinary-language philosophy of, for example, J.L. Austin, and, as a refutation of skepticism, in contextualism and in related attempts to dissolve the skeptical threat. ${ }^{13}$ Both ordinary-language philosophy and contextualism are usually traced back to Wittgenstein. Indeed, Wittgenstein claims in his Philosophical Investigations that he aims at a dissolution of philosophical confusions in such a way that "philosophical problems should completely disappear" (2009: §133). As Duncan Pritchard reads this statement, for Wittgenstein, "philosophy is both the malaise and the cure" (2011b: 201). For Pritchard, Wittgenstein is thus a quietist in the abovementioned sense and can be related to Pyrrhonism in this respect, since, in the words of Pritchard, as the result of Wittgenstein's philosophical practice "we are returned to where we began; we cannot make progress with philosophy. But of course in a very real sense Pyrrhonians are also quietists" (2011b: 201). There is an important difference, though, between Wittgenstein and Pyrrhonism, since Pyrrhonism wants to cure the dogmatist, who actually judges that things really are the way they appear, while Wittgenstein wants to cure us of the aspiration to gain absolute justification. Against this background, Wittgenstein would indeed have us "return to where we began" before we confusedly thought that we should long for absolute justification, while the Pyrrhonians really change the dogmatist's state of mind and transform him into a being that lives on the basis of everyday appearances. But either way, the performative undermining of the quest for absolute objectivity leads to the dissolution of our confusion, no matter if the confusion is that we are or should be objectively justified.

According to the quietist reading, then, we acknowledge the finitude of the human condition through the dissolution of this confusion and, correspondingly, acquiesce in everyday life. However, I think that this acknowledgment also implies a new, albeit non-propositional, understanding of what it means to be finite. As I argued in the introduction, since the notion of 'absolute objectivity' is confused, the notion of 'finitude' is confused either. We still understand this notion metaphorically, but I will argue in the next section that there is an additional, experiential understanding of our finitude that we can achieve through the transformative experience of failing to transcend it. Accordingly, the 'result' of the philosophical practice of Pyrrhonian skepticism and Wittgenstein's philosophy would not just be the quietist acquiescence in common life, but also a new, albeit non-propositional, understanding of the finitude of the human condition. In particular, I think that the personal transformation that is evoked by the Pyrrhonian or Wittgensteinian philosophical practice includes philosophical progress of its own and is not just the result of

13 Cf., e.g., McGinn (1989) and Williams (1991). As a recent attempt to explicitly dissolve skepticism, see also Schönbaumsfeld (2016). 
the theoretical dissolution of our confused philosophical preconception. This also applies to the notion of philosophy as a practice of self-transformation in more general terms. One might argue that the transformative dimension of philosophy simply means that it transforms life as a result of certain philosophical insights that have previously been made at the theoretical level. One example would be that skepticism demonstrates at the theoretical level the fallacies of dogmatism, what at the personal level results in the acquiescence in common life and in the corresponding peace of mind of ataraxia. Against that, I will show by reference to the example of skepticism that philosophy as a practice of self-transformation can evoke epistemically transformative experiences and can thus lead to a transformation of our self-understanding that is philosophically significant in the sense that it goes beyond what had been revealed by previous theoretical results. I argued in the first section that Pyrrhonism does not at all provide theoretical statements that could then lead to a transformation. Instead, it is a performative practice that leads to a personal transformation in the first place. What is more, I think that the transformative experience of skepticism yields an experiential understanding of our finitude that cannot be reached at the theoretical level. We have no theoretical grasp on the notion of 'epistemic finitude' by dint of us having no theoretical grasp on the notion of 'epistemic infinitude.' However, we can still have the experience of failing to be epistemically infinite, and I think that we can thereby gain an experiential understanding of what it means to be finite.

Against my claim that there is such non-propositional insight involved, the therapeutic and particularly the resolute readings of Wittgenstein also propose that his philosophical practice leads to a new understanding, but to an understanding that sees in a quietist way that the original philosophical problems were just nonsensical. According to Alice Crary, the different therapeutic readings agree that Wittgenstein's philosophical methods are "bringing us to the recognition that certain words we are tempted to utter in philosophy are nonsense, that they fail to say anything we want to say" (2000: 7). What is more, according to the resolute reading, Wittgenstein dissolves philosophical problems so completely that there is not even something that they can mean beyond our capability of expressing things in language. In fact, this is one of the main points of the resolute reading. For James Conant, the goal of the philosophical practice of the Tractatus just is to show that there are no ineffable truths whatsoever beyond language. According to Conant (2000: 198), this is the very confusion that Wittgenstein wants to cure us of. This is a strong claim, particularly since Wittgenstein explicitly states in the Tractatus that there is something important beyond language. In his critique of the resolute reading, Peter Hacker (2000: 368 ), for example, points to sentence 6.522 of the Tractatus, which states: "There are, indeed, things that cannot be put into words. 
They make themselves manifest. They are what is mystical." But, of course, the resolute reading can respond that this sentence is part of the performative strategy of the Tractatus and, thus, can be cancelled out.

However, I do not make claims here about the actual goals of Pyrrhonism and Wittgenstein. With respect to the problem of ineffable truths, I want only to indicate very briefly that Pyrrhonian skepticism and Wittgenstein share a religious dimension. In his critique of the resolute reading, Hacker did not quote all of 6.522 of the Tractatus: He skipped Wittgenstein's reference to the mystical. Against that, I think that the mystical is an important aspect of Wittgenstein's philosophy. ${ }^{14}$ There are also strong similarities between Pyrrho's account of skepticism and Indian Buddhism. ${ }^{15}$ It is thus not incidental, on my reading, that Hadot refers to all of 6.522 of the Tractatus when he elucidates the existential aspect of philosophical practice in ancient philosophy (1995: 285). But I leave the problem of the actual goals of Pyrrhonism and Wittgenstein to the respective scholarship. All I want to show in this paper is that the philosophical practice of Pyrrhonism and Wittgenstein can be understood in such a way that although it performatively undermines the quest for absolute objectivity and indeed shows that we are confused about that, it nonetheless yields an important, albeit non-propositional, insight into the finitude of the human condition. Hence, I will now turn to my proposal regarding epistemically transformative experience in Pyrrhonism and Wittgenstein.

\section{4 \\ Beyond Quietism: Transformative Experience}

To begin with, Pierre Hadot has argued not only that for Wittgenstein true philosophy consists of curing itself of philosophy (1959: 973), but also that Wittgenstein's philosophy generally fits into his reading of ancient philosophy (2004). On this reading, philosophy is a practice, but not a quietist one. On the contrary, there explicitly is a kind of progress that is achieved through philosophy, albeit 'spiritual progress'. As Hadot puts it: "Philosophy was a method of spiritual progress which demanded a radical conversion and transformation of the individual's way of being" (1995: 265). What is more, this transformation not only leads to a new way of being, but also includes a new way of seeing or

14 Cf. Gutschmidt (2014). There is a vast literature on Wittgenstein and religion, cf. e.g. Malcolm (1994) and Pritchard (2011a).

15 Cf. Flintoff (1980), McEvilley (1982), Kuzminski (2010) and Schmiedl-Neuburg (2014). Against that, Spinelli (2016) argues that although this might apply to Pyrrho, there is no corresponding religious dimension in Sextus. 
understanding: "Each school had its own therapeutic method, but all of them linked their therapeutics to a profound transformation of the individual's mode of seeing and being" (1995: 83). Against the quietist objection that the Pyrrhonian transformation returns us to where we began, Hadot points out that the skeptical method changes the philosopher's way of being profoundly and thus includes spiritual progress: "The Skeptics, for instance, refused outright to live philosophically, deliberately choosing to 'live like everybody else', although not until after having made a philosophical detour so intense that it is hard to believe that their 'everyday life' was quite so 'everyday' as they seem to have pretended" (1995: 104). ${ }^{16}$ Similarly, Eichorn argues that for Sextus and Clarke the skeptical transformation affects the conduct of everyday life: "It is crucial both to Sextus's and to Clarke's conception of the relationship between philosophy and everyday life that skepticism at the philosophical level does not leave the claims of everyday life untouched" (2014: 132-133). However, neither Hadot nor Eichorn explicate the manner in which the skeptical transformation changes our self-understanding. In what follows, I will argue that the performative undermining of the quest for absolute objectivity can be interpreted as yielding a new, albeit non-propositional, insight into the finitude of the human condition. To this end, I make use of the notion of 'epistemically transformative experience' that was introduced by Laurie Paul in her recent book on decision theory.

In this book, Paul points out that there are certain experiences in life that transform our self-understanding in ways that we cannot anticipate before having had them, as, for example, becoming a parent, fighting as a soldier in a war, or starting a career as a doctor (2004: ch. 3). This initiated a debate in decision theory regarding the problem of making a rational decision in cases in which we cannot evaluate the potential results of a decision without having had the experience that follows from having already made the decision (cf., e.g., Arvan 2015, Pettigrew 2015). For the purpose of my paper, however, it suffices to focus on the very notion of 'transformative experience.' Paul argues that there are two kinds of transformative experience: "They can be epistemically transformative, giving you new information in virtue of your experience. And they can be personally transformative, changing how you experience being who you are"

16 A particular difference to the usual everyday life is also indicated by Sextus: Although the Skeptics indeed live their everyday lives as everybody else according to the appearances ( $P H$ I 23-24), they do not think that the "things which are forced upon them" are by nature bad, as ordinary people do $(P H \mathrm{I} 29-30)$. However, this is not yet the transformation that I am talking about here. The transformation that I am aiming at cannot be found explicitly in Sextus. Even so, I think that his philosophy can be interpreted in that way. 
(2014: 17). She then says that she is focusing in her book on experiences that are both epistemically and personally transformative and that she uses the notion of 'transformative experience' as referring to those experiences: "Having a transformative experience teaches you something new, something that you could not have known before having the experience, while also changing you as a person" (2014: 17). However, when she talks of information and knowledge here, she is not thinking of ordinary theoretical knowledge, but rather of some kind of experiential knowledge. More precisely, she illustrates the idea of epistemic transformation with reference to the thought-experiments of Thomas Nagel and Frank Jackson (2014: 5-6, 8-15). In this context, she employs the notion of knowing what it is like to be in certain experiential states (2014: 11) and is thus alluding to a form of non-propositional knowledge. Even though a transformative experience does not necessarily include new propositional knowledge, it can still be epistemically significant, since we perceive ourselves and the world differently through a personal transformation and we then know, albeit non-propositionally, what it is like to be in this experiential state.

Beyond that, I think that the notion of 'epistemically transformative experience' can be applied to other forms of non-propositional understanding as well. In particular, a philosophical transformation implies not only knowledge of what it is like to have a certain philosophical experience, but also, as a consequence, a new way of seeing the corresponding philosophical problem. It is Paul's conjunction of epistemic and personal transformation that is crucial in this respect. I think that this conjunction allows for an understanding of how philosophical experiences are linked to new, albeit non-propositional, philosophical insights. In a way, the interdependence of experience and understanding can already be found in ancient philosophy. In his introduction to Hadot's Philosophy as a Way of Life, Arnold Davidson, for example, refers to Hadot's concept of spiritual exercises and quotes Hadot as saying, "These exercises are certainly exercises of meditation, but they do not only concern reason; in order to be efficacious, they must link the imagination and affectivity to the work of reason, and therefore all the psychagogical means of rhetoric" (1995: 23). ${ }^{17}$ This can be understood as an example of the conjunction of personal and epistemic transformation, and I thus think that it is fruitful to transpose the notion of 'epistemically transformative experience' from decision theory to experiences that are evoked by philosophical practice. In particular, I want to argue that

17 Hadot generally claims that ancient philosophy "even if it is apparently theoretical and systematic, is written not so much to inform the reader of a doctrinal content but to form him" (1995: 64). He elucidates this, for example, with respect to "the works of Plotinus and Augustine, in which all the detours, starts and stops, and digressions of the work are formative elements" (1995: 64). 
the philosophical practice of Pyrrhonism and Wittgenstein also affects reason, imagination, and affectivity simultaneously, and thereby can evoke epistemically transformative experiences in Laurie Paul's sense.

To show this, my point basically is that although the philosophical practice of Pyrrhonism and Wittgenstein shows that the quest for absolute objectivity is nonsensical at the theoretical level, we still climbed up a ladder while struggling with it, which represents a philosophical transformation. As in the transformative experiences of life in more general terms, we perceive ourselves and the world differently on the top of that ladder, particularly with respect to our finitude. However, I am not claiming that Pyrrhonism or Wittgenstein actually wanted to provoke transformative experiences of this kind. There is, of course, a strong existential aspect in Pyrrhonism, since it is supposed to yield the new attitude of ataraxia. But although Hadot suggests that this includes a kind of spiritual progress, there is no clear-cut evidence that, for example, Sextus Empiricus intended such progress. Similarly, Wittgenstein's philosophy definitely is a kind of philosophical practice, but we do not know for sure whether he intended to provoke epistemically transformative experiences. Be that as it may, my point is that their respective philosophical practice can evoke such experiences and that hence Pyrrhonian skepticism and Wittgenstein's philosophy are not necessarily forms of quietism.

To elaborate this point more thoroughly, I will now briefly discuss Leibniz's question, "Why is there anything at all and not rather nothing?" This question is not discussed in Pyrrhonism, but, albeit shortly, by Wittgenstein. Stanley Cavell, who is regarded as a Neo-Pyrrhonist (Gabriel 2008: 141-148), also refers to this question. With the help of this question, I want to show that a philosophical problem that is confused or nonsensical at the theoretical level can still evoke philosophical experiences that transform our self-understanding. Carl Gustav Hempel, for example, argues that Leibniz's question does not make sense because we cannot even think of an answer (1973: 200). ${ }^{18}$ But Hempel concedes that although the question is a 'logical impossibility', it nonetheless leads to the experience of wonder about the fact of existence (1973: 201202). ${ }^{19}$ Of course, in a way, there is no reason to wonder at the fact of existence, since the question is nonsensical in the end. But in terms of our philosophical self-understanding as finite beings, the unexplainable fact of existence is of the utmost importance, even though the corresponding question is a 'logical impossibility.' In asking this question, we indeed are confused, because

18 He discusses this, of course, from the perspective of his deductive-nomological model of explanation.

19 In this context, Hempel refers to sentence $6.5^{2}$ of the Tractatus, which is closely related to sentence 6.522 that I mentioned in the second section of this paper. 
we cannot even think of an answer. But this is an important confusion that is not simply resolved when we unmask the nonsensical character of the question that evoked the confusion. Instead, we understand ourselves differently after having struggled with it; we see the world in a new way, albeit in a nonpropositional mode: We now wonder at the fact of its existence. As a matter of fact, this is one of the examples of Wittgenstein's notorious notion of running up against the limits of language: "Man has the urge to thrust against the limits of language. Think for instance about one's astonishment that anything exists. This astonishment cannot be expressed in the form of a question and there is no answer to it. Anything we can say must, a priori, be only nonsense. Nevertheless we thrust against the limits of language." ${ }^{20}$ For Wittgenstein, too, the fact of existence leads to the experience of wonder, even though the problem is nonsensical at the theoretical level: "And I will now describe the experience of wondering at the existence of the world by saying: it is the experience of seeing the world as a miracle" (1965: 11$)$. This definitely is a new way of seeing the world, which not only includes the non-propositional knowledge of what it is like to have this experience, but, as a consequence, also yields a nonpropositional understanding of the fact of existence. I thus think that this is an example of an epistemically transformative experience that is philosophically significant. Stanley Cavell explicitly admits that he has had the experience that Wittgenstein talks about (1979: 241), and he also claims that it was part of Wittgenstein's teaching to evoke such experiences (1979: 15). In Cavell's terms, Leibniz's question reveals the mystery of the existence of the world (1979:15). What is more, he relates this mystery not only to Wittgenstein and Heidegger, but also to his concept of a 'truth of skepticism':

An admission of some question as to the mystery of the existence, or the being, of the world is a serious bond between the teaching of Wittgenstein and that of Heidegger. The bond is one, in particular, that implies a shared view of what I have called the truth of skepticism, or what I might call the moral of skepticism, namely, that the human creature's basis in the world as a whole, its relation to the world as such, is not that of knowing, anyway not what we think of as knowing.

1979: 15

Hence, for Cavell, the experience of the mystery of existence leads to a new "basis in the world as a whole" for the human creature. For Wittgenstein, this means seeing the world as a miracle; for Cavell, this means that the relation of 
the human creature to the world is not a relation of knowledge. Either way, the crucial point is that it is the philosophical practice of dealing with a seemingly nonsensical problem that yields a new basis in the world. Similarly, Pyrrhonian skepticism uses paradoxical arguments, and its skeptical method is explicitly self-defeating. But instead of just being nonsense, the Pyrrhonian philosophical practice also aims at the transformation of the self. While we do not know whether this transformation was intended to be epistemically transformative, I think that it certainly can be. In Cavell's terms, the skeptical experience leads to a new basic relation to the world and to others that he also describes as the attitude of acceptance or acknowledgment (1988: 109). Out of this transformation towards a new attitude, we understand something new about the finiteness of our knowledge and our dependence on acknowledgment. However, this is a non-propositional form of understanding that is linked to the corresponding experience, since the original philosophical problem is nonsensical in the end and since, correspondingly, the notion of finitude is confused. The status of this understanding is, thus, best understood if one interprets Cavell's attitude of acknowledgment as the result of a philosophical experience that is epistemically transformative in Laurie Paul's sense. The knowledge of what it is like to have the attitude of acknowledgment implies a non-propositional understanding of the finiteness of our knowledge. That being said, I think it is quite obvious that the philosophical practice of Pyrrhonism and Wittgenstein can evoke such epistemically transformative experiences as well. Both undermine performatively our quest for absolute objectivity, which can yield a nonpropositional understanding of the finitude of the human condition.

\section{Transformative Experience in Modern Skepticism}

As I have argued in the first section of this paper, the notion of philosophy as a transformative practice has a long tradition. Accordingly, transformative experiences that are evoked by philosophical problems can be found not only in Pyrrhonism and Wittgenstein, but throughout the history of philosophy. The ancient experience of ataraxia and the philosophical experience of wonder that I just referred to seem to be rather positive sentiments. However, in Plato and Aristotle, the moment of wonder (thaumazein) was decidedly a troubling experience. Since there is no reliable evidence concerning the experiential aspect in ancient skepticism, I will now briefly turn to modern skepticism, which seems to evoke rather negative experiences as well. David Hume, for example, describes the existential dimension of skepticism in his Treatise of Human $\mathrm{Na}$ ture, where he concedes that all his skeptical enquiries lead him to "philosophical melancholy and delirium" (2007a: 175). In his book on Wittgenstein, Saul 
Kripke reports, albeit very briefly, that he had "something of an eerie feeling" when he contemplated the skeptical paradox that he found in the Philosophical Investigations (1982: 21). Similarly, Cavell claims that the insight into the finiteness of our knowledge makes the world uncanny to us. It belongs to Cavell's aforementioned concept of the 'truth of skepticism' that we have to find a new way of trusting to the world and others as a result of skeptical disturbances. As Cavell puts it in his lecture on the Uncanniness of the Ordinary: "The return of what we accept as the world will then present itself as a return of the familiar, which is to say, exactly under the concept of what Freud names the uncanny. That the familiar is a product of a sense of the unfamiliar and of the sense of a return means that what returns after skepticism is never (just) the same" (1988: 100). As I have argued in the previous section, I think this is best understood as a transformative experience that results in a new attitude that is linked to a new self-understanding with respect to the finiteness of our knowledge. Similarly, when Hume leaves his study and returns to the everyday world, he is even able to laugh about the skeptical threat (2007b: 117$)$, but he also argues that skepticism demonstrates "the whimsical condition of mankind, who must act and reason and believe; though they are not able, by their most diligent enquiry, to satisfy themselves concerning the foundation of these operations, or to remove the objections, which may be raised against them" (2007 b: 117). This, too, is best understood as a transformative experience that leads to a new attitude in which we acknowledge the whimsical human condition.

The corresponding philosophical experiences can be very strong and powerful. To begin with, Cavell claims that the skeptical insight into the groundlessness of our everyday practices is terrifying:

That on the whole we do ["make, and understand, the same projections" of "words ... into further contexts"] is a matter of our sharing routes of interest and feeling, senses of humor and of significance and of fulfillment, of what is outrageous, of what is similar to what else, what a rebuke, what forgiveness, of when an utterance is an assertion, when an appeal, when an explanation - all the whirl of organism Wittgenstein calls "forms of life." Human speech and activity, sanity and community, rest upon nothing more, but nothing less, than this. It is a vision as simple as it is difficult, and as difficult as it is (and because it is) terrifying.

1969: 52

John McDowell refers to this passage and claims that the terrifying insight into the finitude of all the mentioned human practices leads to vertigo: "The terror of which Cavell writes at the end of this marvelous passage is a sort of vertigo, 
induced by the thought that there is nothing that keeps our practices in line except the reactions and responses we learn in learning them. The ground seems to have been removed from under our feet" (1998: 207). A similar vertiginous experience can already be found in Descartes, who refers at the beginning of his Second Meditation to the ground-shaking effect of his skeptical enquiry:

So serious are the doubts into which I have been thrown as a result of yesterday's meditation that I can neither put them out of my mind nor see any way of resolving them. It feels as if I have fallen unexpectedly into a deep whirlpool which tumbles me around so that I can neither stand on the bottom nor swim up to the top.

1996: 16

Not least, in his recent book, Duncan Pritchard discusses this existential dimension of skepticism. Although he attempts to refute skepticism with reference to Wittgenstein's hinge propositions, which he takes to provide a sufficient foundation of our knowledge from within our practices, he also concedes that the insight into the finitude of our epistemic practices, as opposed to the aspiration to achieve an external foundation of our knowledge, induces vertigo: "I call this psychological state epistemic vertigo $[. .$.$] in order to capture the idea$ that it is essentially a kind of phobic reaction to one's epistemic predicament" (2016: 6). In a way, even the Pyrrhonian transformation towards a life without dogma can be a vertiginous experience, as Eichorn indicates: "He [Sextus] has seen all his beliefs and preconceptions thrown into question by philosophy. He has felt the whirlpool pull of epistemic nihilism. But he has also seen philosophy overthrow itself and has come out the other side with a peculiar attitude toward his own beliefs, an attitude shorn of dogmatism" (2014: 133).

All in all, I think that these examples are best understood with the help of the notion of 'epistemically transformative experience.' With respect to this notion, I have argued that the attitude of a life without dogma or of acknowledging the finiteness of our knowledge includes a form of non-propositional understanding. The original philosophical problem is nonsensical at the theoretical level and can be undermined performatively, but this performance still reveals a non-propositional insight into the finitude of the human condition. In particular, this insight cannot be reached at the theoretical level, since the theoretical notion of 'finitude' is confused. Finally, even though this kind of transformative understanding is not explicitly mentioned in Pyrrhonism or Wittgenstein, it can be argued, with the help of Paul's notion, that their respective philosophical practice can evoke such epistemically transformative experiences and is thus not necessarily a quietist practice. 
To sum up, I have argued that the philosophical practice of Pyrrhonism and Wittgenstein can be interpreted in such a way that it performatively undermines our quest for absolute objectivity and thereby reveals experientially the finitude of the human condition. Similarly, Hume's skeptical experiences point to the "whimsical condition of mankind" that we have to accept and, with reference not only to Wittgenstein, but also to Kant and Heidegger, Neo-Pyrrhonist Cavell argues that the limits of knowledge belong to the human condition: "Both Wittgenstein and Heidegger continue [to develop], by reinterpreting [it], Kant's insight that the limitations of knowledge are not failures of it" (1979: 241). Now, the reference to Paul's notion of 'epistemically transformative experience' is crucial for an adequate understanding of the status of this insight. In Pyrrhonism, there is no theoretical statement about the limits of reason, and, following the therapeutic and resolute readings of Wittgenstein, the quest for absolute objectivity is confused and the idea of an external standpoint is an illusion, so that the 'insight' into the finitude of the human condition seems to be confused as well. However, with the help of Paul's notion, this insight can be understood as a form of non-propositional knowledge that is linked to philosophical experiences. In particular, the non-propositional insight into our finitude is linked to the experience of the failure of the quest for absolute objectivity. In a way, the notion of a non-propositional insight through the experience of a failure resembles the phenomenological notion that we understand something new about our everyday practices in the very moment of a disruption of these practices. Cavell relates this notion to skepticism:

Something very similar is what I want to say in formulating my abiding interest in material object skepticism - that what skepticism questions or denies my knowledge of is the world of objects I inhabit, is the world. As elsewhere, the abnormal provides our access to the normal. I recognize from the failure of what skepticism regards as my knowledge of objects what it is my everyday life with objects consists in.

1979: 448

I want to suggest here that the status of this recognition can be conceived of as the result of epistemically transformative experiences that are evoked by the philosophical practice of skepticism. In compliance with Paul's conjunction of personal and epistemic transformation, this practice leads to a new attitude that accepts the limits of reason and at the same time yields a non-propositional understanding of these limits. The corresponding experiences can be troubling, since the world might become uncanny and we might feel vertiginous; but as 
Cavell also points out, this must not lead to despair (1979: 237). It is, after all, an important part of the skeptical tradition from Pyrrhonism via Hume to Wittgenstein and Cavell that we get back to our everyday life, transformed but not desperate or despairing. What is more, this kind of transformative understanding does not come to an end. We do not undergo a skeptical transition once and for all. Instead, this form of understanding is bound to the performance of the skeptical practice and cannot be separated from it. As I quoted above, Sextus claims that skeptics do not know that knowledge is impossible, but that they are "still investigating" in this matter. Similarly, Wittgenstein struggled with philosophical problems until his death; he did not come to a quietist rest. Accordingly, the epistemically transformative experiences that are evoked by the practice of philosophy do not conclusively resolve our puzzlements about the human condition. Although I think that certain transformative experiences in philosophy reveal the finitude of the human condition, this does not provide a stable, permanent state of peace of mind. Instead, the philosophical struggle with this finitude is an ongoing, potentially endless, task.

This also applies to this paper. It does not provide a theoretical solution of the problem of our finitude, since the very notion of 'finitude' is fully understandable only when it is conceived of as an example of the ongoing practice of skepticism. Moreover, since the notion of 'finitude' is the crucial point of this paper, it is itself fully understandable only by those who have had the sort of transformative experience it seeks to describe; thus, it is itself part of an ongoing philosophical practice that aims at personal transformation. ${ }^{21}$

\section{References}

Arvan, M. 2015. "How to Rationally Approach Life's Transformative Experiences," Philosophical Psychology 28: 1199-1218.

Bailey, A. 2002. Sextus Empiricus and Pyrrhonean Scepticism. Oxford: Clarendon Press. Barnes, J. 1982. "The Beliefs of a Pyrrhonist," Proceedings of the Cambridge Philological Society 28: 1-29.

Bett, R. 1993. "Scepticism and Everyday Attitudes in Ancient and Modern Philosophy," Metaphilosophy 24: 363-381.

21 I thank the Volkswagen Foundation for a Post-doctoral Fellowship at the University of Chicago and James Conant for hosting my stint in the US. I am also grateful to the audience of the Wittgenstein Workshop at the University of Chicago and to Máté Veres, Emidio Spinelli, and two anonymous reviewers for their comments on an earlier draft of this paper. I owe an enormous debt to Roger Eichorn for his intense comments on this paper and for numerous fruitful conversations about the status of skepticism. 
Burnyeat, M.F. 1983. "Can the Skeptic Live His Skepticism?" In M.F. Burnyeat (ed.), The Skeptical Tradition, 117-148. Berkeley: University of California Press.

Burnyeat, M.F. 1998. "The sceptic in His Place and Time." In M.F. Burnyeat and M. Frede (eds.), The Original Sceptics: A Controversy, 92-126. Indianapolis: Hackett.

Cavell, S. 1969. Must We Mean What We Say? A Book of Essays. New York: Charles Scribner's Sons.

Cavell, S. 1979. The Claim of Reason. Oxford: Oxford University Press.

Cavell, S. 1988. In Quest of the Ordinary. Lines of Skepticism and Romanticism. Chicago: University of Chicago Press.

Conant, J. 200o. "Elucidation and Nonsense in Frege and Early Wittgenstein." In R. Read and A. Crary (eds.), The New Wittgenstein, 174-217. London: Routledge.

Crary, A. 2000. "Introduction." In R. Read and A. Crary (eds.), The New Wittgenstein, 1-18. London: Routledge.

Descartes, R. 1996. Meditations on First Philosophy. (J. Cottingham ed.) Cambridge: Cambridge University Press.

Eichorn, R.E. 2014. "How (Not) To Read Sextus Empiricus," Ancient Philosophy 34: 121-149.

Flintoff, E. 1980. "Pyrrho and India," Phronesis 25: 88-108.

Fogelin, R.J. 1987. Wittgenstein. London: Routledge and Kegan Paul.

Gabriel, M. 2008. Antike und Moderne Skepsis. Hamburg: Junius.

Gutschmidt, R. 2014. "Gewissheit und Vertrauen. Der quasi-religöse Status der Angelsätze bei Wittgenstein." In C. Demuth and N. Schneidereit (eds.), Interexistenzialität und Unverfügbarkeit. Leben in einer menschlichen Welt, 131-149. Freiburg, München: Alber.

Gutschmidt, R. 2016. "Skepticism, Metaphors and Vertigo. Wittgenstein and Cavell on the Human Condition," Wittgenstein Studies 7: 131-147.

Hacker, P.M.S. 200o. “Was He Trying to Whistle It?” In R. Read and A. Crary (eds.), The New Wittgenstein, 353-388. London: Routledge.

Hadot, P. 1959. "Wittgenstein philosophe du langage-II," Critique 150: 972-983.

Hadot, P. 1995. Philosophy as a Way of Life. Oxford: Blackwell.

Hadot, P. 2004. Wittgenstein et les limites du langage. Paris: Librairie Philosophique J. Vrin.

Hempel, C.G. 1973. "Science Unlimited?," The Annals of the Japan Association for Philosophy of Science 14: 187-202.

Hume, D. 2007a. A Treatise of Human Nature. Edited by D.F. Norton and M.J. Norton. Oxford: Oxford University Press.

Hume, D. 2007b. An Enquiry concerning Human Understanding. Edited by P. Millican. Oxford: Oxford University Press.

Kripke, S.A. 1982. Wittgenstein on Rules and Private Language. Cambridge, MA: Harvard University Press. 
Kuzminski, A. 2010. Pyrrhonism: How the Ancient Greeks Reinvented Buddhism. Lanham: Lexington Books.

Machuca, D.E. (ed.) 2011. Pyrrhonism in Ancient, Modern, and Contemporary Philosophy. Dordrecht: Springer.

Malcolm, N. 1994. Wittgenstein: A Religious Point of View? Ithaca, NY: Cornell University Press.

McDowell, J. 1998. “Non-Cognitivism and Rule-Following." In his Mind, Value, and Reality, 198-218. Cambridge, MA: Harvard University Press.

McEvilley, T. 1982. "Pyrrhonism and Mādhyamika," Philosophy East and West 32: 3-35.

McGinn, M. 1989. Sense and Certainty. A Dissolution of Scepticism. Oxford: Blackwell.

Nussbaum, M.C. 1994. The Therapy of Desire. Princeton: Princeton University Press.

Paul, L.A. 2014. Transformative Experience. Oxford: Oxford University Press.

Pettigrew, R. 2015. "Transformative Experience and Decision Theory," Philosophy and Phenomenological Research 91: 766-774.

Plant, B. 2004. "The End(s) of Philosophy: Rhetoric, Therapeia and Wittgenstein's Pyrrhonism," Philosophical Investigations 27: 222-257.

Pritchard, D. 2011. "Wittgensteinian Quasi-Fideism," Oxford Studies in the Philosophy of Religion 4: 145-159.

Pritchard, D. 201b. “Wittgensteinian Pyrrhonism.” In D.E. Machuca (ed.), Pyrrhonism in Ancient, Modern, and Contemporary Philosophy, 193-202. Dordrecht: Springer.

Pritchard, D. 2016. Epistemic Angst: Radical Skepticism and the Groundlessness of Our Believing. Princeton: Princeton University Press.

Schmiedl-Neuburg, H. 2014. "Pyrrhonische Skepsis und die Indische Philosophie," Zeitschrift für Kulturphilosophie 2014/ 2: 343-365.

Schönbaumsfeld, G. 2016. The Illusion of Doubt. Oxford: Oxford University Press.

Sextus Empiricus. 1997. Against the Ethicists. Translated by R. Bett. Oxford: Clarendon Press.

Sextus Empiricus. 2000. Outlines of Scepticism. Translated by J. Annas and J. Barnes. Cambridge: Cambridge University Press.

Sextus Empiricus. 2005. Against the Logicians. Translated by R. Bett. Cambridge: Cambridge University Press.

Sluga, H. 2004. "Wittgenstein and Pyrrhonism." In W. Sinnott-Armstrong (ed.), Pyrrhonian Skepticism, 99-117. Oxford: Oxford University Press.

Spinelli, E. 2016. "Le dieu est la cause la plus active': Sextus Empiricus contre la théologie dogmatique." In A.-I. Bouton-Touboulic and C. Lévy (eds.), Scepticisme et religion. Constantes et evolutions, de la philosophie hellénistique à la philosophie médiévale, 89-102. Turnhout: Brepols Publishers.

Virvidakis, S. 2008. "Varieties of Quietism," Philosophical Inquiry 30/1-2: 157-175.

Vogt, K. 2015. Skepsis und Lebenspraxis: Das pyrrhonische Leben ohne Meinungen. München, Freiburg: Alber. 
Waismann, F. 1965. "Notes on Talks with Wittgenstein," The Philosophical Review 74: 12-16.

Wallgren, T. 2006. Transformative Philosophy. Socrates, Wittgenstein, and the Democratic Spirit of Philosophy. Lanham: Lexington Books.

Watson, R.A. 1969. "Sextus and Wittgenstein," The Southern Journal of Philosophy 7: 229-236.

Williams, M. 1991. Unnatural Doubts. Epistemological Realism and the Basis of Scepticism. Oxford: Blackwell.

Wittgenstein, L. 1965. "Lecture on Ethics," The Philosophical Review 74: 3-12.

Wittgenstein, L. 2005. The Big Typescript. Translated by C.G. Luckhardt and M.A.E. Aue. Oxford: Blackwell.

Wittgenstein, L. 2009. Philosophical Investigations. Translated by P.M.S. Hacker and J. Schulte. Oxford: Blackwell. 